See discussions, stats, and author profiles for this publication at: https://www.researchgate.net/publication/277345266

\title{
Effect of rumen-protected choline supplementation on metabolic and performance responses of transition dairy cows
}

Article in Journal of Animal Science · April 2015

DOI: $10.2527 /$ jas. $2014-8606$

CITATIONS

11

5 authors, including:

Reinaldo Fernandes Cooke

Texas A\&M University

204 PUBLICATIONS 1,545 CITATIONS

SEE PROFILE

Rodrigo S. Marques

Oregon State University

82 PUBLICATIONS 252 CITATIONS

SEE PROFILE

Some of the authors of this publication are also working on these related projects:

\section{READS}

143

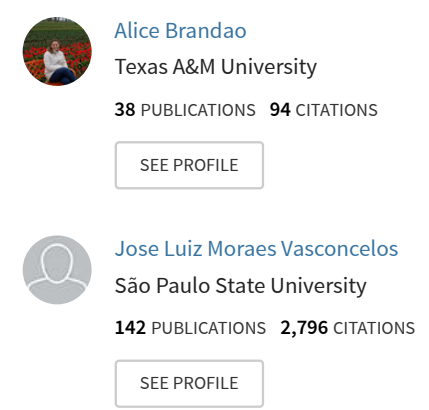

Physiologic, health, and production responses of dairy cows supplemented with an immunomodulatory feed ingredient during the transition period View project 


\title{
Effects of rumen-protected choline supplementation on metabolic and performance responses of transition dairy cows ${ }^{1}$
}

\author{
T. Leiva, ${ }^{*}$ R. F. Cooke ${ }^{2} \dagger$ A. P. Brandão, ${ }^{*}$ R. S. Marques, $\uparrow$ and J. L. M. Vasconcelos ${ }^{* 2}$ \\ *Department of Animal Production, São Paulo State University, Botucatu 18168-000, Brazil; \\ and $\dagger$ Eastern Oregon Agricultural Research Center, Oregon State University, Burns 97720
}

\begin{abstract}
The objective of this experiment was to compare metabolic and milk production parameters in dairy cows supplemented and nonsupplemented with rumen-protected choline (RPC) during the transition period. Twenty-three nonlactating, multiparous, pregnant Holstein cows were ranked by BW and BCS $21 \mathrm{~d}$ before expected date of calving and immediately were assigned to receive $(n=12)$ or not receive (control; $n=$ 11) RPC until $45 \mathrm{~d}$ in milk (DIM). Cows supplemented with RPC received (as-fed basis) 50 and $100 \mathrm{~g} / \mathrm{d}$ of RPC ( $18.8 \%$ choline) before and after calving, respectively. Before calving, cows were maintained in 2 drylot pens according to treatment with ad libitum access to corn silage, and individually they received (as-fed basis) $3 \mathrm{~kg} /$ cow daily of a concentrate. Upon calving, cows were moved to 2 adjacent drylot pens according to treatment, milked twice daily, offered (as-fed basis) $35 \mathrm{~kg} /$ cow daily of corn silage, and individually received a concentrate formulated to meet their nutritional requirements after milking. The RPC was individually offered to cows as a topdressing into the morning concentrate feeding. Before calving, cow BW and BCS were recorded weekly, and blood samples were collected
\end{abstract}

every $5 \mathrm{~d}$ beginning on $\mathrm{d}-21$ relative to expected calving date. Upon calving and until 45 DIM, BW and BCS were recorded weekly, individual milk production was recorded daily, and milk samples were collected once a week and analyzed for fat, protein, and total solids. Blood samples were collected every other day from 0 to 20 DIM and every $5 \mathrm{~d}$ from 20 to 45 DIM. Based on actual calving dates, cows receiving RPC or control began receiving treatments $16.8 \pm 1.7$ and $17.3 \pm 2.0 \mathrm{~d}$ before calving, respectively. No treatment effects were detected $(P \geq 0.18)$ on postpartum concentrate intake, $\mathrm{BW}$ and $\mathrm{BCS}$, or serum concentrations of cortisol, $\beta$-hydroxybutyrate, NEFA, glucose, and IGF-I. Cows supplemented with RPC had greater $(P \leq 0.01)$ mean serum haptoglobin and insulin concentrations compared with control. Cows supplemented with RPC had greater $(P<0.01)$ milk protein, total solids $(P<0.01)$, and milk fat concentrations $(P=0.09)$ compared with control. No treatment effects were detected $(P \geq 0.43)$ for milk yield parameters, such as fat-corrected or solids-corrected milk yield. In conclusion, supplementing RPC to transition dairy cows increased haptoglobin and insulin concentrations and benefited milk composition.

Key words: choline, dairy cows, haptoglobin, insulin, milk production, transition period

\section{INTRODUCTION}

\footnotetext{
${ }^{1}$ The Fundação de Amparo à Pesquisa do Estado de São Paulo (São Paulo, Brazil) provided financial support for T. Leiva (grant 2012/25390-3).

${ }^{2}$ Corresponding authors: vasconcelos@fmvz.unesp.br and reinaldo. cooke@oregonstate.edu. Dr. Reinaldo Cooke is also affiliated as graduate professor to the Programa de Pós-Graduaçãoem Zootecnia/ Faculdade de Medicina Veterinária e Zootecnia, UNESP - Univ. Estadual Paulista, Botucatu, SP, Brazil, 18618-970.

Received October 12, 2014.

Accepted January 14, 2015.
}

Fatty liver is known to affect and subsequently impact hepatic function in almost $50 \%$ of transition dairy cows (Jorritsma et al., 2000). Due to the critical role of hepatocytes on metabolic processes within the transition period (Strang et al., 1998a,b), fatty liver has been shown to impair health and performance of dairy cattle (Grummer, 1995). Hence, several efforts were conducted to develop strategies that mitigate this syndrome. One example is rumen-protected choline (RPC) supplementation, a key component of 
lipoproteins responsible for hepatic lipid export (Yao and Vance, 1988). Accordingly, transition dairy cattle receiving RPC had reduced hepatic lipid accumulation (Zom et al., 2011) and improved health (Ardalan et al., 2010) and milk production (Chung et al., 2009) compared with nonsupplemented cohorts.

Transition dairy cows experience several physiological changes that impact immune and productive functions (Goff and Horst, 1997). One example is the acute-phase reaction, which is activated in response to stress, trauma, and injuries associated with parturition and onset of lactation, with the intent of restoring homeostasis (Trevisi and Bertoni, 2008). A major component of the acute-phase reaction is the hepatic synthesis of acute-phase proteins such as haptoglobin, a protein that prevents $\mathrm{Fe}$ loss and has bacteriostatic effects (Petersen et al., 2004). Therefore, the acute-phase reaction and its hepatic products appear to be required for proper homeostasis restoration following calving and beginning of lactation (Silvestre et al., 2011a,b). Based on this rationale, we hypothesized that RPC supplementation to dairy cows enhances hepatic haptoglobin synthesis during the transition period, which may help explain the health and production benefits associated with RPC. Hence, the objective was to compare metabolic and milk production parameters in dairy cows supplemented and nonsupplemented with RPC before calving and during early lactation.

\section{MATERIALS AND METHODS}

This experiment was conducted at the São Paulo State University Lageado Experimental Station, located in Botucatu, São Paulo, Brazil. All animals utilized were cared for in accordance with acceptable practices and experimental protocols reviewed and approved by the São Paulo State University Animal Ethics Committee.

\section{Animals and Diets}

Twenty-three nonlactating, multiparous, pregnant Holstein cows (initial mean \pm SE; BW $=619 \pm 18$ $\mathrm{kg}, \mathrm{BCS}=3.11 \pm 0.07$ ) were ranked by BW and BCS (Wildman et al., 1982) $21 \mathrm{~d}$ before the expected date of calving and immediately were assigned to receive ( $n$ $=12$ ) or not receive (control; $n=11$ ) RPC (CholiPearl, $18.8 \%$ of choline from choline $\mathrm{Cl}$; Kemin Agrifoods South America, Indaiatuba, São Paulo, Brazil). The RPC source utilized herein is based on choline $\mathrm{Cl}$ treated with a patented spray-freezing procedure that reduces ruminal degradation and increases circulating availability of organic compounds (Brake et al., 2013). Treatment administration began $21 \mathrm{~d}$ before the expected date of calving and ended when each cow reached $45 \mathrm{~d}$ in milk (DIM).
Cows supplemented with RPC received (as-fed basis) 50 and $100 \mathrm{~g} / \mathrm{d}$ of RPC before and after calving, respectively.

Before calving, cows were maintained in 2 drylot pens according to treatment ( 1 pen/treatment) with ad libitum access to corn silage ( $1.5 \mathrm{~m}$ of linear bunk space/cow), water, and a commercial prepartum mineral mix $(25 \% \mathrm{Ca}, 4.7 \% \mathrm{~S}, 4.5 \% \mathrm{Mg}, 3.3 \% \mathrm{Cl}, 0.001 \%$ $\mathrm{Se}, 422,000 \mathrm{IU} / \mathrm{kg}$ of vitamin A, 21,200 IU/kg of vitamin D3, and $0.211 \%$ of vitamin E; Milk Ionic, M. Cassab Tecnologia Animal, São Paulo, Brazil). Cows individually received $3 \mathrm{~kg} / \mathrm{cow}$ daily of a concentrate through self-locking head gates once daily $(0800 \mathrm{~h})$, and concentrate composition was (as-fed basis) $45.5 \%$ of soybean meal, $45.5 \%$ of ground corn, and $9.0 \%$ of the aforementioned commercial prepartum mineral mix. All cows completely consumed their concentrate allocation within $30 \mathrm{~min}$ after feeding.

Upon calving, cows were moved to adjacent drylot pens according to treatment ( 1 pen/treatment), with ad libitum access to water and a commercial lactation mineral mix $(22 \% \mathrm{Ca}, 7.5 \% \mathrm{P}, 6.5 \% \mathrm{Na}, 1.0 \% \mathrm{~K}, 3.6 \% \mathrm{Mg}$, $2.0 \% \mathrm{~S}, 0.003 \% \mathrm{Co}, 0.115 \% \mathrm{Cu}, 0.004 \% \mathrm{I}, 0.220 \% \mathrm{Mn}$, $0.003 \% \mathrm{Se}, 0.400 \% \mathrm{Zn}, 400,000 \mathrm{IU} / \mathrm{kg}$ of vitamin A, $100,000 \mathrm{IU} / \mathrm{kg}$ of vitamin D3, and $0.150 \%$ of vitamin E; Milk MAC, M. Cassab Tecnologia Animal). Cows were milked twice daily in a side-by-side milking system $(0600$ and $1700 \mathrm{~h})$. Cows were group-fed (as-fed basis) $35 \mathrm{~kg} / \mathrm{cow}$ daily of corn silage ( $1.5 \mathrm{~m}$ of linear bunk space/cow), and they individually received a concentrate through self-locking head gates immediately after milking. Concentrate composition was (as-fed basis) $40.5 \%$ of soybean meal, $56.8 \%$ of ground corn, and $2.7 \%$ of the aforementioned commercial lactation mineral mix. Concentrate intake was adjusted weekly throughout the experimental period using the Spartan Dairy Ration Evaluator/Balancer (version 3.0; Michigan State University, East Lansing, MI) according to DIM, $\mathrm{BW}, \mathrm{BCS}$, and milk yield with fat and protein concentrations set at $3.5 \%$ and $3.2 \%$, respectively. Concentrate intake during the initial $3 \mathrm{~d}$ of lactation was adjusted as previously reported, but with milk yield of $20 \mathrm{~kg} / \mathrm{cow}$ daily. All cows completely consumed their concentrate allocation within 30 min after feeding.

Before and after calving, cows were rotated among drylot pens every $5 \mathrm{~d}$ to account for any potential effects of pen on the variables evaluated herein. The RPC was offered (50 and $100 \mathrm{~g} / \mathrm{d}$ of RPC to yield 9.4 and $18.8 \mathrm{~g} / \mathrm{d}$ of choline cation, respectively) in the amounts recommended by the manufacturer (Kemin Agrifoods South America) and previous research (Hartwell et al., 2000; Zahra et al., 2006; Cooke et al., 2007), and topdressed daily into the morning concentrate feeding of each cow receiving RPC. Samples of the offered corn silage, prepartum, and lactation concentrates were collected every 
$2 \mathrm{wk}$, pooled into one sample, and analyzed for nutrient content via wet chemistry procedures by a bromatology laboratory (3rlab, Belo Horizonte, Brazil). Calculations of $\mathrm{ME}, \mathrm{NE}_{\mathrm{L}}$, and NEM used the equation proposed by the NRC (2001). Concentration of DM was $39.2 \%$ in corn silage, $89.3 \%$ in prepartum concentrate, and $89.0 \%$ in lactation concentrate. Nutritive value (DM basis) was $53 \% \mathrm{NDF}, 33 \% \mathrm{NFC}, 2.24 \mathrm{Mcal} / \mathrm{kg}$ of ME, $1.39 \mathrm{Mcal} /$ $\mathrm{kg}$ of NEL, $1.39 \mathrm{Mcal} / \mathrm{kg}$ of NEM, and $8.1 \% \mathrm{CP}$ for corn silage; $12 \% \mathrm{NDF}, 58 \% \mathrm{NFC}, 2.76 \mathrm{Mcal} / \mathrm{kg}$ of ME, 1.80 $\mathrm{Mcal} / \mathrm{kg}$ of NEL, $1.91 \mathrm{Mcal} / \mathrm{kg}$ of NEM, and $24.2 \% \mathrm{CP}$ for prepartum concentrate; and 13\% NDF, 58\% NFC, $2.99 \mathrm{Mcal} / \mathrm{kg}$ of ME, $1.92 \mathrm{Mcal} / \mathrm{kg}$ of NEL, $2.04 \mathrm{Mcal} /$ $\mathrm{kg}$ of NEM, and $23.1 \% \mathrm{CP}$ for postpartum concentrate.

\section{Sampling}

Cows were monitored daily during the entire experimental period for incidence of health disorders such as retained placenta or mastitis, as well as incidence of morbidity or mortality (Lima et al., 2012).

Before calving, cow BW and BCS were scheduled to be recorded once weekly ( $\mathrm{d}-21,-14$, and -7 relative to expected calving date), whereas BCS was assessed (Wildman et al., 1982) by 2 evaluators that were blinded to distribution of cows across treatments. Blood samples were also scheduled to be collected every $5 \mathrm{~d}$ beginning on $\mathrm{d}-21$ relative to expected calving date $(\mathrm{d}-21,-16$, $-11,-6$, and -1$)$, immediately before concentrate feeding (0800 h). Based on actual calving dates, cows receiving RPC or control began receiving treatments $16.8 \pm 1.7$ and $17.3 \pm 2.0 \mathrm{~d}$ before calving, respectively. Hence, the day of BW and BCS assessment or blood collection relative to actual calving date was rounded into the nearest prescheduled sampling date (d -21, $-16,-11,-6$, or -1$)$.

After calving (d 0), cows were evaluated for BW and BCS (Wildman et al., 1982; same 2 blinded evaluators as before calving). Beginning the day after calving, BW and BCS (Wildman et al., 1982; same 2 blinded evaluators as before calving) were recorded weekly, while individual milk production was recorded daily until d 45 of lactation. Milk samples were collected once a week from each cow during both milkings of the day, combined into 1 daily sample (50 mL from each milking), which was analyzed for fat, protein, and total solid content using infrared spectrometry (method 972.16; AOAC, 1999) by a commercial laboratory (Clínica do Leite; Universidade de São Paulo, Piracicaba, Brazil). Blood samples were collected every other day from d 0 to 20 of lactation and every $5 \mathrm{~d}$ from d 20 to 45 of lactation, immediately before morning concentrate feeding $(0600 \mathrm{~h})$.

All blood samples were obtained from either the coccygeal vein or artery into commercial blood collection tubes (Vacutainer, $10 \mathrm{~mL}$; Becton Dickinson, Franklin
Lakes, NJ), placed immediately on ice, centrifuged at $3,000 \times g$ at $4^{\circ} \mathrm{C}$ for 30 min for serum collection, and stored at $-20^{\circ} \mathrm{C}$ on the same day of collection. All samples were analyzed for serum concentrations of glucose (colorimetric kit \#G7521; Pointe Scientific, Inc., Canton, MI), $\beta$-hydroxybutyrate (BHBA; colorimetric kit \#H7587; Pointe Scientific, Inc.), NEFA (colorimetric kit HR Series NEFA- 2; Wako Pure Chemical Industries Ltd. USA, Richmond, VA), haptoglobin (colorimetric assay; Cooke and Arthington, 2013), IGF-I (human-specific ELISA kit SG100; R\&D Systems, Inc., Minneapolis, MN; validated by Cooke et al., 2012), cortisol and insulin (chemiluminescent enzyme immunoassay, Immulite 1000; Siemens Medical Solutions Diagnostics, Los Angeles, CA). Insulin to glucose ratio (I:G) was determined by dividing insulin and glucose concentrations within each sampling time (Bernhard et al., 2012). Concentrations of glucose, NEFA, and insulin were used to determine preprandial revised quantitative insulin sensitivity check index (RQUICKI). This methodology has been used to estimate insulin sensitivity in dairy cows (Holtenius and Holtenius, 2007; Gross et al., 2011; Grünberg et al., 2011), which is an approach to assess insulin resistance according to the equation proposed by Perseghin et al. (2001): RQUICKI $=1 /[\log ($ glucose $)+\log ($ insulin $)+$ $\log ($ NEFA) $]$. The intra- and interassay CV were, respectively, $1.2 \%$ and $3.1 \%$ for glucose, $6.9 \%$ and $5.0 \%$ for BHBA, $1.7 \%$ and $2.0 \%$ for NEFA, $4.6 \%$ and $8.2 \%$ for haptoglobin, $3.1 \%$ and $4.5 \%$ for IGF-I, $1.6 \%$ and $1.4 \%$ for cortisol, and $0.5 \%$ and $3.1 \%$ for insulin.

\section{Statistical Analysis}

All analyses were performed with the MIXED procedure of SAS (SAS Inst. Inc., Cary, NC; version 9.3) and Satterthwaite approximation to determine the denominator df for the tests of fixed effects, using cow as the experimental unit and cow(treatment) as a random variable. Data were analyzed using values obtained from the sampling before the beginning of treatment administration and days receiving treatment before calving as independent covariates. The model statement used for analysis of BW and BCS change, as well as initial (no covariate included), postcalving, and final $\mathrm{BCS}$ and $\mathrm{BW}$ during the experiment contained the effects of treatment. The model statement used for analysis of weekly BW and BCS contained the effects of treatment, week, and the resultant interaction. The model statement used for analysis of daily milk production, daily concentrate intake, and serum variables contained the effects of treatment, day, and the resultant interaction. The specified term for the repeated statements was week for BCS and BW and day for the remaining analysis, with cow(treatment) as subject. The 

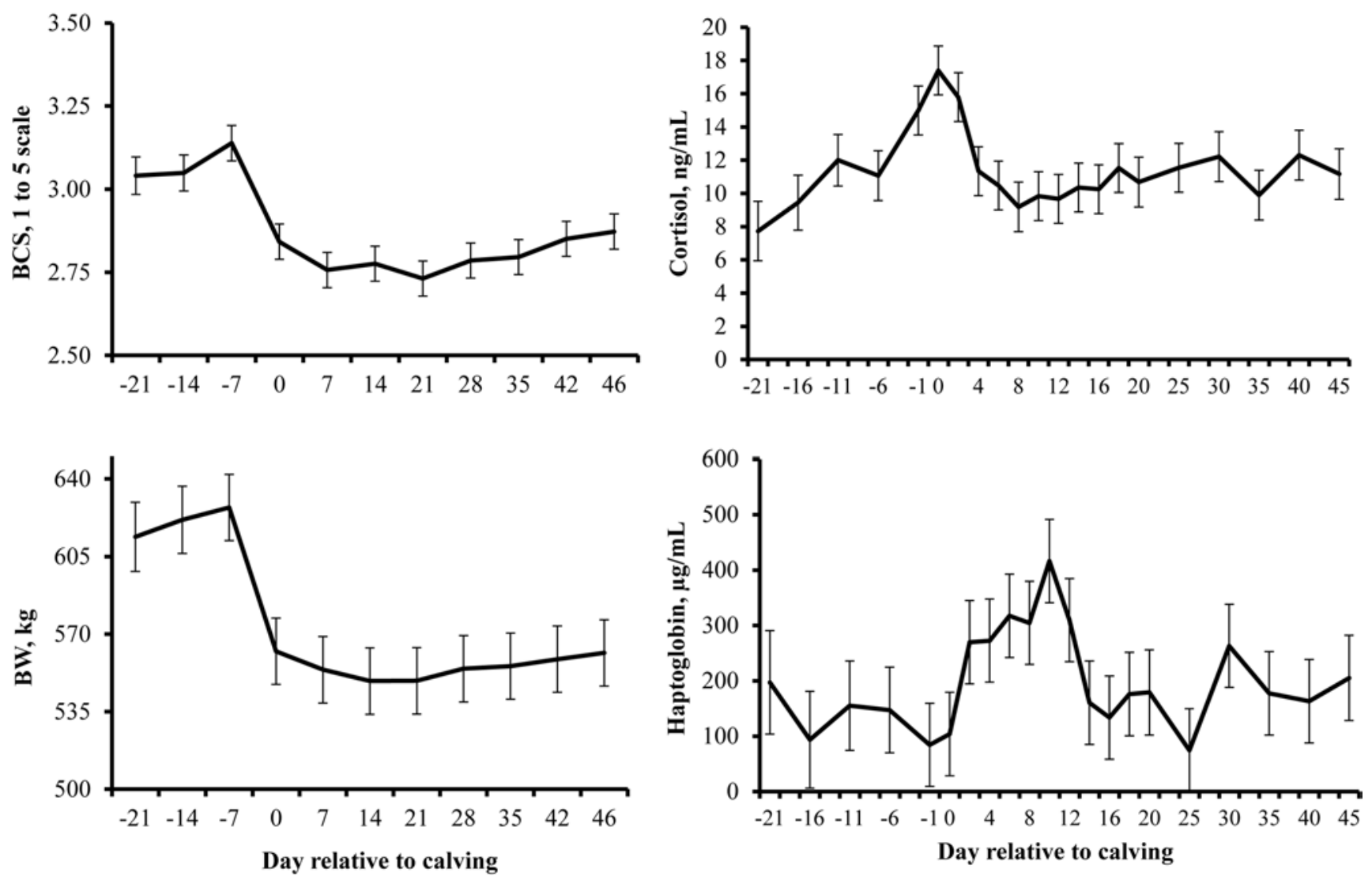

Figure 1. Body weight, BCS, serum cortisol, and haptoglobin concentrations of dairy cows evaluated $(n=23)$ from d -21 to 45 relative to calving (d $0)$ in the present experiment. A day effect was detected $(P<0.01)$ for all parameters.

covariance structure utilized for all repeated statements was autoregressive, which provided the best fit for these analyses according to the Akaike information criterion. Significance was set at $P \leq 0.05$, and tendencies were determined if $P>0.05$ and $\leq 0.10$. Results were separated using LS means and are reported as covariately adjusted least squares means according to treatment effects if no interactions were significant or according to the highest-order interaction detected.

\section{RESULTS AND DISCUSSION}

No treatment $\times$ day or week interactions were detected $(P \geq 0.35)$ for any of the variables evaluated herein. Nevertheless, Fig. 1 and 2 report day effects $(P<0.01)$ to demonstrate that cows utilized in this experiment experienced the $\mathrm{BW}, \mathrm{BCS}$, and physiological changes associated with calving and beginning of lactation (VazquezAñon et al., 1994; Drackley, 1999; Jorritsma et al., 2003). Furthermore, no health disorders, morbidity, or mortality were detected during the experiment.

No treatment effects were detected on BW $(P \geq 0.58)$ and BCS $(P \geq 0.18)$ parameters on calving (Table 1) or throughout the experimental period (data not shown). Previous research has also reported similar BW and BCS parameters in transition cows supplemented or nonsupplemented with RPC and attributed this outcome to similar DMI treatment groups (Piepenbrink and Overton, 2003; Elek et al., 2008). Conversely, Zom et al. (2011) reported increased DMI in cows supplemented with RPC, but without a similar outcome in BW and BCS. In the present experiment, corn silage intake was not evaluated but was provided at the same limited daily rate to pens housing lactating cows supplemented or nonsupplemented with RPC. In addition, concentrate was provided equally to RPC-supplemented and control cows before calving, whereas postpartum concentrate DMI was similar $(P$ $=0.27)$ among treatments $(9.14 \mathrm{vs} .9 .89 \mathrm{~kg} / \mathrm{d}$ on asfed basis for cows supplemented or nonsupplemented with RPC; SEM = 0.55). Hence, although the present experiment did not fully evaluate treatment effects on DMI, it also demonstrates that RPC supplementation does not impact BW and BCS changes associated with calving and beginning of lactation (Fig. 1).

No treatment effects were detected $(P=0.77)$ for serum cortisol concentrations (Table 2), indicating that both treatment groups experienced a similar corticosteroid reaction on calving and beginning of lactation (Fig. 1; Hudson et al., 1976). To our knowledge, no other research has evaluated the impact of RPC supplementation on neuroendocrine stress reactions in transition dairy 

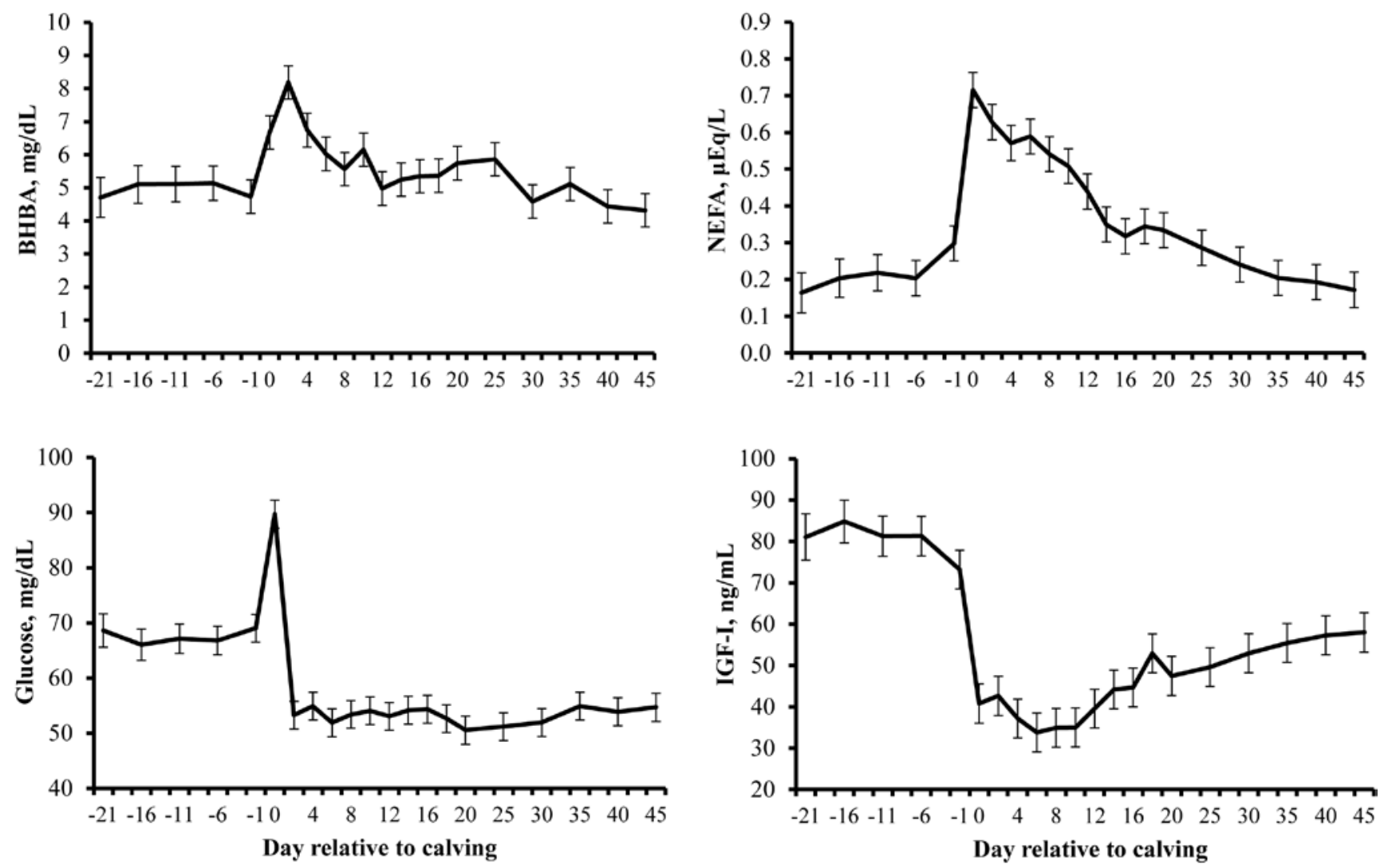

Figure 2. Serum concentrations of $\beta$-hydroxybutyrate (BHBA), glucose, NEFA, and IGF-I of dairy cows evaluated ( $n=23)$ from d -21 to 45 relative to calving $(\mathrm{d} 0)$ in the present experiment. A day effect was detected $(P<0.01)$ for all parameters.

cows. However, cows receiving RPC had greater $(P=$ 0.01) mean serum haptoglobin concentration compared with control cows (Table 2), suggesting that RPC supplementation increased the acute-phase response elicited by stress, trauma, injuries, and inflammation associated with parturition and onset of lactation (Fig. 1; Trevisi and Bertoni, 2008; Cray et al., 2009). We speculate that this outcome is associated with a potential decrease in hepatic lipid accumulation and enhanced hepatic function in cows supplemented with RPC. Supporting our rationale, previous research documented that RPC supplementation alleviated hepatic lipidosis (Elek et al., 2008; Zom et al., 2011) and enhanced hepatic activity (Goselink et al., 2013) during the transition period, whereas synthesis and subsequent circulating concentrations of haptoglobin are dependent on hepatic function (Williams et al., 1961; Imbert-Bismut et al., 2001). Silvestre et al. $(2011 \mathrm{a}, \mathrm{b})$ reported that supplementing safflower oil, a proinflammatory nutraceutical, to transition dairy cows increased the periparturient acute-phase response required for coping with the stressful and highly contaminated postpartum period and enhanced productive and reproductive responses. Conversely, others have reported a positive association among circulating haptoglobin concentrations and fatty liver in dairy cattle (Murata et al., 2004; Ametaj et al., 2005). Therefore, treatment effects detected herein on serum haptoglobin cannot be fully elucidated and deserve further investigation, given that the present experiment did not evaluate liver parameters but is first to evaluate serum haptoglobin in transition cows receiving supplemental RPC.

No treatment effects were detected $(P \geq 0.68)$ for serum concentrations of BHBA, NEFA, glucose, and IGF-I (Table 2), suggesting that cows from both treatments experienced a similar nutritional and metabolic challenge on calving and beginning of lactation (Fig. 2; Vazquez-Añon et al., 1994; Jorritsma et al., 2003). Others have also reported similar serum concentrations of these serum variables between transition dairy cows supplemented or nonsupplemented with RPC (Chung et al., 2009; Janovick Guretzky et al., 2006; Zahra et al., 2006), despite reduced hepatic lipid content in RPCsupplemented cows (Zom et al., 2011). Conversely, Cooke et al. (2007) reported reduced NEFA in cows supplemented with RPC and associated this effect with a concurrent decrease in hepatic lipid accumulation. Nevertheless, Cooke et al. (2007) evaluated dry Holstein cows during the far-off period exposed to nutrient restriction, which did not account for parturition and lactation effects on NEFA metabolism (Bell, 1995).

Cows supplemented with RPC had greater $(P<$ $0.01)$ mean serum insulin concentrations during the experiment compared with control cows (Table 2). Circulating insulin concentrations are primarily mod- 
Table 1. Body weight and BCS of dairy cows supplemented with rumen-protected choline (RPC; $n=12$ ) or nonsupplemented (control; $n=11$ ) before and for $45 \mathrm{~d}$ after calving ${ }^{1,2}$

\begin{tabular}{lcccc}
\hline \hline Item & Choline & Control & SEM & $P$-value \\
\hline Body weight, $\mathrm{kg}$ & & & & \\
Initial BW (d -21), kg & 620 & 624 & 23 & 0.90 \\
Postcalving BW (d 0), kg & 558 & 566 & 23 & 0.80 \\
BW change (d -21 to 0), kg & -62 & -58 & 10 & 0.78 \\
Final BW (d 46), kg & 567 & 556 & 17 & 0.65 \\
BW change (d 0 to 46), kg & 9 & -10 & 25 & 0.58 \\
BCS ${ }^{3}$ & & & & \\
Initial BCS (d -21) & 3.02 & 3.15 & 0.08 & 0.28 \\
Postcalving BCS (d 0) & 2.84 & 2.84 & 0.07 & 0.98 \\
BCS change (d -21 to 0), kg & -0.18 & -0.30 & 0.06 & 0.18 \\
Final BCS (d 46) & 2.92 & 2.82 & 0.06 & 0.25 \\
BCS W change (d 0 to 46), kg & 0.08 & -0.02 & 0.06 & 0.26 \\
\hline
\end{tabular}

\footnotetext{
${ }^{1}$ Before calving, cows received corn silage for ad libitum consumption
} and were offered $3 \mathrm{~kg} / \mathrm{cow}$ daily (as-fed-basis) concentrate based on corn, soybean meal, and commercial mineral mix (45.5:45.5:9.0 ratio; as-fed basis). Based on actual calving dates, cows receiving RPC or control began receiving treatments $16.8 \pm 1.7$ and $17.3 \pm 2.0 \mathrm{~d}$ before calving, respectively. After calving, cows received $35 \mathrm{~kg} / \mathrm{cow}$ daily (as-fed basis) of corn silage and were offered a concentrate based on corn, soybean meal, and commercial mineral mix (56.8:40.5:2.7 ratio; as-fed basis). Concentrate intake during lactation was adjusted weekly using the Spartan Dairy Ration Evaluator/Balancer (version 3.0; Michigan State University, East Lansing, MI), according to days in milk, BW, BCS, and milk yield with fat and protein concentrations set at $3.5 \%$ and $3.2 \%$, respectively. Cows supplemented with RPC received (as-fed basis) 50 and $100 \mathrm{~g} / \mathrm{d}$ of RPC (CholiPearl, 18.8\% of choline from choline Cl; Kemin Agrifoods South America, Indaiatuba, São Paulo, Brazil) before and after calving, respectively, which was mixed with $50 \mathrm{~g}$ of finely ground corn and topdressed daily into the morning concentrate feeding of each RPC-supplemented cow. Finely ground corn $(50 \mathrm{~g} / \mathrm{cow})$ was also topdressed into the morning concentrate feeding of control cows, but without the addition of the RPC.

${ }^{2}$ Before calving, BW and BCS were scheduled to be recorded weekly beginning on $\mathrm{d}-21$ relative to expected calving date $(\mathrm{d}-21,-16,-11,-6$, and -1) before concentrate feeding $(0800 \mathrm{~h})$. According to actual calving dates, $\mathrm{BW}$ and $\mathrm{BCS}$ were rounded into the nearest prescheduled sampling date. Upon calving, BW and BCS were recorded weekly until d 45 of lactation.

${ }^{3}$ According to Wildman et al. (1982) and assessed by 2 evaluators that were blinded to distribution of cows across treatments.

ulated by circulating glucose and nutrient intake in cattle (Vizcarra et al., 1998; Butler, 2003). Therefore, treatment effects detected for serum insulin were unexpected based on the lack of treatment effects on serum glucose and other markers of nutritional intake such as BHBA, NEFA, and IGF-I (Vazquez-Añon et al., 1994; Drackley, 1999; Jorritsma et al., 2003; Table 2) and the similar corn silage and concentrate intake between treatments during the postpartum period. Once could speculate that the greater insulin concentrations in RPC-supplemented cows could be attributed to reduced insulin sensitivity (Leiva et al., 2014), which is a common syndrome during the transition period and positively associated with incidence of fatty liver in dairy cattle (Hayirli, 2006). However,
Table 2. Serum parameters and revised quantitative insulin sensitivity check index (RQUICKI) of dairy cows supplemented with rumen-protected choline (RPC; $n=12$ ) or nonsupplemented (control; $n=11$ ) before and for $45 \mathrm{~d}$ after calving ${ }^{1,2}$

\begin{tabular}{lcccc}
\hline \hline Item & Choline & Control & SEM & $P$-value \\
\hline Beta-hydroxybutyrate, mg/dL & 5.59 & 5.37 & 0.38 & 0.68 \\
Cortisol, ng/mL & 11.1 & 11.6 & 1.2 & 0.77 \\
Glucose, $\mathrm{mg} / \mathrm{dL}$ & 58.6 & 58.2 & 1.8 & 0.86 \\
Haptoglobin, $\mu \mathrm{g} / \mathrm{mL}$ & 242 & 158 & 24 & 0.01 \\
IGF-I, ng/mL & 52.8 & 54.6 & 4.7 & 0.79 \\
Insulin to glucose ratio & 0.66 & 0.46 & 0.16 & 0.37 \\
Insulin, pmol/1 & 37.3 & 25.0 & 2.4 & $<0.01$ \\
NEFA, $\mu$ Eq/L & 0.363 & 0.352 & 0.045 & 0.87 \\
RQUICKI & 1.11 & 1.47 & 0.41 & 0.54 \\
\hline
\end{tabular}

${ }^{1}$ Before calving, cows received corn silage for ad libitum consumption and were offered $3 \mathrm{~kg} / \mathrm{cow}$ daily (as-fed-basis) concentrate based on corn, soybean meal, and commercial mineral mix (45.5:45.5:9.0 ratio; as-fed basis). Based on actual calving dates, cows receiving RPC or control began receiving treatments $16.8 \pm 1.7$ and $17.3 \pm 2.0 \mathrm{~d}$ before calving, respectively. After calving, cows received $35 \mathrm{~kg} / \mathrm{cow}$ daily (as-fed basis) of corn silage and were offered a concentrate based on corn, soybean meal, and commercial mineral mix (56.8:40.5:2.7 ratio; as-fed basis). Concentrate intake during lactation was adjusted weekly using the Spartan Dairy Ration Evaluator/Balancer (version 3.0; Michigan State University, East Lansing, MI), according to days in milk, BW, BCS, and milk yield with fat and protein concentrations set at $3.5 \%$ and $3.2 \%$, respectively. Cows supplemented with RPC received (as-fed basis) 50 and $100 \mathrm{~g} / \mathrm{d}$ of RPC (CholiPearl, 18.8\% of choline from choline Cl; Kemin Agrifoods South America, Indaiatuba, São Paulo, Brazil) before and after calving, respectively, which was mixed with $50 \mathrm{~g}$ of finely ground corn and topdressed daily into the morning concentrate feeding of each RPC-supplemented cow. Finely ground corn $(50 \mathrm{~g} / \mathrm{cow})$ was also topdressed into the morning concentrate feeding of control cows, but without the addition of the RPC.

${ }^{2}$ Before calving, blood samples were scheduled to be collected every $5 \mathrm{~d}$ beginning on $\mathrm{d}-21$ relative to expected calving date $(\mathrm{d}-21,-16,-11$, -6 , and -1$)$ before concentrate feeding $(0800 \mathrm{~h})$. According to actual calving dates, samples collected were rounded into the nearest prescheduled sampling date. Upon calving, collected every other day from d 0 to 20 of lactation and every $5 \mathrm{~d}$ from d 20 to 45 of lactation, immediately before morning concentrate feeding $(0600 \mathrm{~h})$.

${ }^{3}$ According to Perseghin et al. (2001).

no treatment effects were detected $(P \geq 0.37)$ for $\mathrm{I}: \mathrm{G}$ ratio or RQUICKI (Table 2), which are methodologies used to estimate insulin sensitivity in dairy cattle (Subiyatno et al., 1996; Hayirli et al., 2001; Grünberg et al., 2011). Alternatively, circulating insulin concentrations are positively associated with acute-phase and inflammatory reactions (Steiger et al., 1999; Waldron et al., 2003). Pancreatic insulin synthesis is enhanced by inflammatory compounds such as cytokines (Eizirik et al., 1995; Andersson et al., 2001), perhaps to increase energy utilization by the body (Waggoner et al., 2009). Hence, the greater inflammatory state of RPC-supplemented cows based on treatment effects detected for serum haptoglobin (Horadagoda et al., 1999) may explain, at least partially, treatment effects detected for serum insulin concentrations. 
Table 3. Milk production parameters of dairy cows supplemented with rumen-protected choline (RPC; $n=12$ ) or nonsupplemented (control; $n=11$ ) before and for $45 \mathrm{~d}$ after calving ${ }^{1,2}$

\begin{tabular}{lcccr}
\hline \hline Item & Choline & Control & SEM & $P$-value \\
\hline Milk yield, kg/d & 29.1 & 30.6 & 1.3 & 0.43 \\
Milk protein, \% & 3.32 & 3.17 & 0.03 & $<0.01$ \\
Milk fat, \% & 3.51 & 3.29 & 0.09 & 0.09 \\
Milk total solids, \% & 12.4 & 11.9 & 0.1 & $<0.01$ \\
$3.5 \%$ fat-corrected milk, kg/d & 29.4 & 28.6 & 1.6 & 0.70 \\
$12 \%$ solids-corrected milk, kg/d & 29.9 & 30.2 & 1.3 & 0.87 \\
\hline
\end{tabular}

${ }^{1}$ Before calving, cows received corn silage for ad libitum consumption and were offered $3 \mathrm{~kg} / \mathrm{cow}$ daily (as-fed-basis) concentrate based on corn, soybean meal, and commercial mineral mix (45.5:45.5:9.0 ratio; as-fed basis). Based on actual calving dates, cows receiving RPC or control began receiving treatments $16.8 \pm 1.7$ and $17.3 \pm 2.0 \mathrm{~d}$ before calving, respectively. After calving, cows received $35 \mathrm{~kg} / \mathrm{cow}$ daily (as-fed basis) of corn silage and were offered a concentrate based on corn, soybean meal, and commercial mineral mix (56.8:40.5:2.7 ratio; as-fed basis). Concentrate intake during lactation was adjusted weekly using the Spartan Dairy Ration Evaluator/Balancer (version 3.0; Michigan State University, East Lansing, MI), according to days in milk, BW, BCS, and milk yield with fat and protein concentrations set at 3.5 and $3.2 \%$, respectively. Cows supplemented with RPC received (as-fed basis) 50 and $100 \mathrm{~g} / \mathrm{d}$ of RPC (CholiPearl, 18.8\% of choline from choline Cl; Kemin Agrifoods South America, Indaiatuba, São Paulo, Brazil) before and after calving, respectively, which was mixed with $50 \mathrm{~g}$ of finely ground corn and topdressed daily into the morning concentrate feeding of each RPC-supplemented cow. Finely ground corn $(50 \mathrm{~g} / \mathrm{cow})$ was also topdressed into the morning concentrate feeding of control cows, but without the addition of the RPC.

${ }^{2}$ Individual milk production was recorded daily until d 45 of lactation. Milk samples were collected once a week from each cow during the first milking of the day $(0600 \mathrm{~h})$ and analyzed for fat, protein, and total solid content using infrared spectrometry (method 972.16; AOAC, 1999; Clínica do Leite; Universidade de São Paulo, Piracicaba, Brazil).

No treatment effects were detected $(P=0.43)$ for milk yield, whereas RPC-supplemented cows had greater $(P<0.01)$ milk protein concentration and total solids concentration and tended $(P=0.09)$ to have greater milk fat concentration compared with control cows (Table 3 ). Nevertheless, fat-corrected and solids-corrected milk yield were similar $(P \geq 0.70)$ among treatments. The effects of RPC on milk production parameters have been variable (Sales et al., 2010), with research studies reporting increased (Zahra et al., 2006; Chung et al., 2009; Elek et al., 2008) or similar (Hartwell et al., 2000; Janovick Guretzky et al., 2006; Zom et al., 2011) milk yield when RPC is supplemented to transition dairy cows. Furthermore, research studies reporting greater milk production in RPC-supplemented cows reported increased (Zahra et al., 2006) or similar DMI between treatment groups (Chung et al., 2009; Elek et al., 2008), suggesting that benefits of RPC on milk production are not entirely associated with a potential increase in DMI (Sales et al., 2010).

Milk composition in dairy cattle is directly impacted by nutrient intake (NRC, 2001), whereas postpartum corn silage and concentrate intake were similar between treatments in the present experiment. Hence, RPC supplementation impacted milk concentrations of protein, fat, and total solids despite similar nutrient intake between treatments. The increased milk protein concentration in RPC-supplemented cows detected herein has also been reported by other research studies (Elek et al., 2008; Zom et al., 2011) and by the metaanalysis compiled by Sales et al. (2010). This outcome has been attributed to the fact that RPC acts as a methyl donor and allows more Met to be available for protein synthesis in the mammary gland (Pinotti et al., 2002; Brusemeister and Sudekum, 2006). Milk protein synthesis is also stimulated by circulating insulin (McGuire et al., 1995; Griinari et al., 1997; Mackle et al., 1999); therefore, treatment effects detected for milk protein concentration can also be associated with the greater serum insulin concentrations in RPCsupplemented cows (Table 2).

The effects of RPC supplementation on milk fat have also been variable (Sales et al., 2010), with research studies reporting increased (Sharma and Erdman, 1989; Emanuele et al., 2007; Ondarza et al., 2007) or similar (Hartwell et al., 2000; Janovick Guretzky et al., 2006; Zahra et al., 2006) milk fat concentrations in RPC-supplemented cows compared with control cohorts. Supporting our results, Erdman et al. (1984) suggested that RPC aids the transport of FFA mobilized from adipose tissue during the periparturient period from adipose tissues through the liver and into the mammary gland, and hence increased the availability of lipids for milk fat synthesis. On the other hand, RPC supplementation has not been positively associated with milk concentrations of lactose and other components (Hartwell et al., 2000; Janovick Guretzky et al., 2006; Sales et al., 2010). Hence, the increase in milk total solids concentration of RPCsupplemented cows detected herein should be attributed to treatment effects detected for milk fat and protein concentrations (Table 3 ).

In conclusion, supplementing RPC to transition dairy cows enhanced the serum haptoglobin response associated with calving and beginning of lactating, increased serum insulin concentrations independently of insulin resistance parameters, and benefited milk fat, protein, and total solids concentrations without improving milk yield. Hence, results from this experiment suggest that enhanced periparturient acute-phase protein response is one of the mechanisms by which RPC supplementation benefits health and production parameters of transition dairy cows. Nevertheless, research is still warranted to fully comprehend the role of RPC on acute-phase and inflammatory responses in prepartum and postpartum dairy cattle. 


\section{LITERATURE CITED}

Ametaj, B. N., B. J. Bradford, G. Bobe, R. A. Nafikov, Y. Lu, J. W. Young, and D. C. Beitz. 2005. Strong relationship between mediators of the acute phase response and fatty liver in dairy cows. Can. J. Anim. Sci. 85:165-175.

Andersson, A. K., M. Flodstrom, and S. Sandler. 2001. Cytokineinduced inhibition of insulin release from mouse pancreatic $\beta$-cells deficient in inducible nitric oxide synthase. Biochem. Biophys. Res. Commun. 281:396-403.

AOAC. 1999. Official method of analysis. 16th ed. Assoc. Off. Anal. Chem., Arlington, VA.

Ardalan, M., K. Rezayazdi, and M. Dehghan-Banadaky. 2010. Effect of rumen-protected choline and methionine on physiological and metabolic disorders and reproductive indices of dairy cows. J. Anim. Physiol. Anim. Nutr. 94:e259-e265.

Bell, A. W. 1995. Regulation of organic nutrient metabolism during transition from late pregnancy to early lactation. J. Anim. Sci. 73:2804-2819.

Bernhard, B. C., N. C. Burdick, R. J. Rathmann, J. A. Carroll, D. N. Finck, M. A. Jennings, T. R. Young, and B. J. Johnson. 2012. Chromium supplementation alters both glucose and lipid metabolism in feedlot cattle during the receiving period. J. Anim. Sci. 90:4857-4865.

Brake, D. W., E. C. Titgemeyer, M. J. Brouk, C. A. Macgregor, J. F. Smith, and B. J. Bradford. 2013. Availability to lactating dairy cows of methionine added to soy lecithins and mixed with a mechanically extracted soybean meal. J. Dairy Sci. 96:3064-3074.

Brusemeister, F., and K.-H. Sudekum. 2006. Rumen-protected choline for dairy cows: The in situ evaluation of a commercial source and literature evaluation of effects on performance and interactions between methionine and choline metabolism. Anim. Res. 55:93-104.

Butler, W. R. 2003. Energy balance relationships with follicular development, ovulation and fertility in postpartum dairy cows. Livest. Prod. Sci. 83:211-218.

Chung, Y. H., N. E. Brown, C. M. Martinez, T. W. Cassidy, and G. A. Varga. 2009. Effects of rumen-protected choline and dry propylene glycol on feed intake and blood parameters for Holstein dairy cows in early lactation. J. Dairy Sci. 92:2729-2736.

Cooke, R. F., and J. D. Arthington. 2013. Concentrations of haptoglobin in bovine plasma determined by ELISA or a colorimetric method based on peroxidase activity. J. Anim. Physiol. Anim. Nutr. 97:531-536.

Cooke, R. F., B. I. Cappellozza, M. M. Reis, D. W. Bohnert, and J. L. M. Vasconcelos. 2012. Plasma progesterone concentration in beef heifers receiving exogenous glucose, insulin, or bovine somatotropin. J. Anim. Sci. 90:3266-3273.

Cooke, R. F., N. Silva del Rio, D. Z. Caraviello, S. J. Bertics, M. H. Ramos, and R. R. Grummer. 2007. Supplemental choline for prevention and alleviation of fatty liver in dairy cattle. J. Dairy Sci. 90:2413-2418.

Cray, C., J. Zaias, and N. H. Altman. 2009. Acute phase response in animals: A review. Comp. Med. 59:517-526.

Drackley, J. K. 1999. Biology of dairy cows during the transition period: The final frontier? J. Dairy Sci. 82:2259-2273.

Eizirik, D. L., S. Sandler, N. Welsh, L. Juntti-Berggren, and P. O. Berggren. 1995. Interleukin-1 B-induced stimulation of insulin release in mouse pancreatic islets is related to diacylglycerol production and protein kinase $\mathrm{C}$ activation. Mol. Cell. Endocrinol. 111:159-165.
Elek, R., J. R. Newbold, I. Gaal, L. Wagner, and F. Husveth. 2008. Effects of rumen-protected choline supplementation on milk production and choline supply of periparturient dairy cows. Animal 2:1595-1601.

Emanuele, S., T. Hickley, and R. Carvalho. 2007. Effect of rumen protected choline (Reashure) and rumen protected methionine on milk yield, and composition in lactating cows. J. Dairy Sci. 90(Suppl. 1):352.

Erdman, R. A., R. D. Shaver, and J. H. Vandersall. 1984. Dietary choline for the lactating cow: Possible effects on milk fat synthesis. J. Dairy Sci. 67:410-415.

Goff, J. P., and R. L. Horst. 1997. Physiological changes at parturition and their relationship to metabolic disorders. J. Dairy Sci. $80: 1260-1268$.

Goselink, R. M. A., J. van Baal, H. C. A. Widjaja, R. A. Dekker, R. L. G. Zom, M. J. de Veth, and A. M. van Vuuren. 2013. Effect of rumen-protected choline supplementation on liver and adipose gene expression during the transition period in dairy cattle. J. Dairy Sci. 96:1102-1116.

Griinari, J. M., M. A. McGuire, D. A. Dwyer, D. E. Bauman, and D. L. Palmquist. 1997. Role of insulin in the regulation of milk fat synthesis in dairy cows. J. Dairy Sci. 80:1076-1084.

Gross, J., H. A. van Dorland, F. J. Schwarz, and R. M. Bruckmaier. 2011. Endocrine changes and liver mRNA abundance of somatotropic axis and insulin system constituents during negative energy balance at different stages of lactation in dairy cows. J. Dairy Sci. 94:3484-3494.

Grummer, R. R. 1995. Impact of changes in organic nutrient metabolism on feeding the transition dairy cow. J. Anim. Sci. 73:2820-2833.

Grünberg, W., S. S. Donkin, and P. D. Constable. 2011. Periparturient effects of feeding a low dietary cation-anion difference diet on acid-base, calcium, and phosphorus homeostasis and on intravenous glucose tolerance test in highproducing dairy cows. J. Dairy Sci. 94:727-745.

Hartwell, J. R., M. J. Cecava, and S. S. Donkin. 2000. Impact of dietary rumen undegradable protein and rumen-protected choline on intake, peripartum liver triacylglyceride, plasma metabolites and milk production in transition dairy cows. J. Dairy Sci. 83:2907-2917.

Hayirli, A. 2006. The role of exogenous insulin in the complex of hepatic lipidosis and ketosis associated with insulin resistance phenomenon in postpartum dairy cattle. Vet. Res. Commun. 30:749-774.

Hayirli, A., D. R. Bremmer, S. J. Bertics, M. T. Socha, and R. R. Grummer. 2001. Effect of chromium supplementation on production and metabolic parameters in periparturient dairy cows. J. Dairy Sci. 84:1218-1230.

Horadagoda, N. U., K. M. Knox, H. A. Gibbs, S. W. Reid, A. Horadagoda, S. E. Edwards, and P. D. Eckersall. 1999. Acute phase proteins in cattle: Discrimination between acute and chronic inflammation. Vet. Rec. 144:437-441.

Holtenius, P., and K. Holtenius. 2007. A model to estimate insulin sensitivity in dairy cows. Acta Vet. Scand. 49:29-31.

Hudson, S., M. Mullford, W. G. Whittlestone, and E. Payne. 1976. Bovine plasma corticoids during parturition. J. Dairy Sci. 59:744-746.

Imbert-Bismut, F., V. Ratziu, L. Pieroni, F. Charlotte, Y. Benhamou, and T. Poynard. 2001. Biochemical markers of liver fibrosis in patients with hepatitis $\mathrm{C}$ virus infection: A prospective study. Lancet 357:1069-1075. 
Janovick Guretzky, N. A., D. B. Carlson, J. E. Garrett, and J. K. Drackley. 2006. Lipid metabolite profiles and milk production for Holstein and Jersey cows fed rumen-protected choline during the periparturient period. J. Dairy Sci. 89:188-200.

Jorritsma, R., H. Jorritsma, Y. H. Schukken, and G. H. Wentink. 2000. Relationships between fatty liver and fertility and some periparturient diseases in commercial Dutch dairy herds. Theriogenology 54:1065-1074.

Jorritsma, R., T. Wensing, T.A.M. Kruip, P.L.A.M. Vos, and J.P.T.M. Noordhuizen. 2003. Metabolic changes in early lactation and impaired reproductive performance in dairy cows. Vet. Res. 34:11-26.

Leiva, T., R. F. Cooke, A. C. Aboin, F. L. Drago, R. Gennari, and J. L. M. Vasconcelos. 2014. Effects of excessive energy intake and supplementation with chromium propionate on insulin resistance parameters in non-lactating dairy cows. J. Anim. Sci. 92:775-782.

Lima, F. S., M. F. Sá Filho, L. F. Greco, and J. E. P. Santos. 2012 Effects of feeding rumen-protected choline on incidence of diseases and reproduction of dairy cows. Vet. J. 193:140-146.

Mackle, T. R., D. A. Dwyer, K. L. Invartsen, P. Y. Chouinard, J. M. Lynch, D. M. Barbano, and D. E. Bauman. 1999. Effects of insulin and amino acids on milk protein concentration and yield from dairy cows. J. Dairy Sci. 82:1512-1524.

McGuire, M. A., J. M. Griinari, D. A. Dwyer, and D. E. Bauman. 1995. Role of insulin in the regulation of mammary synthesis of fat and protein. J. Dairy Sci. 78:816-824.

Murata, H., N. Shimada, and M. Yoshioka. 2004. Current research on acute phase proteins in veterinary diagnosis: An overview. Vet. J. 168:28-40.

NRC. 2001. Nutrient requirements of dairy cattle. Natl. Acad. Sci., Washington, DC.

Ondarza, M. B., S. Emanuele, and D. Putnam. 2007. Effect of rumen protected choline (Reashure) supplemented to high producing cows on milk production, milk components, and intake. J. Dairy Sci. 90(Suppl. 1):353.

Perseghin, G., A. Caumo, M. Caloni, G. Testolin, and L. Luzi. 2001. Incorporation of the fasting plasma FFA concentration into QUICKI improves its association with insulin sensibility in nonobese individuals. J. Clin. Endocrinol. Metab. 86:4776-4781.

Petersen, H. H., J. P. Nielsen, and P. M. H. Heegaard. 2004. Application of acute phase protein measurement in veterinary clinical chemistry. Vet. Res. 35:163-187.

Piepenbrink, M. S., and T. R. Overton. 2003. Liver metabolism and production of cows fed increasing amounts of rumen-protected choline during the periparturient period. J. Dairy Sci. 86:1722-1733.

Pinotti, L., A. Baldi, and V. Dell'Orto. 2002. Comparative mammalian choline metabolism with emphasis on the high-yielding dairy cow. Nutr. Res. Rev. 15:315-332.

Sales, J., P. Homolka, and V. Koukolová. 2010. Effect of dietary rumen-protected choline on milk production of dairy cows: A meta-analysis. J. Dairy Sci. 93:3746-3754.

Sharma, B. K., and R. A. Erdman. 1989. Effects of dietary and abomasally infused choline on milk production responses of lactating dairy cows. J. Nutr. 119:248-254.

Silvestre, F. T., T. S. M. Carvalho, N. Francisco, J. E. P. Santos, C. R. Staples, T. C. Jenkins, and W. W. Thatcher. 2011a. Effects of differential supplementation of fatty acids during the peripartum and breeding periods of Holstein cows: I. Uterine and metabolic responses, reproduction, and lactation. J. Dairy Sci. 94:189-204.
Silvestre, F. T., T. S. M. Carvalho, P. C. Crawford, J. E. P. Santos, C. R. Staples, T. C. Jenkins, and W. W. Thatcher. 2011b. Effects of differential supplementation of fatty acids during the peripartum and breeding periods of Holstein cows: II. Neutrophil fatty acids and function, and acute phase proteins. J. Dairy Sci. 94:2285-2301.

Steiger, M., M. Senn, G. Altreuther, D. Werling, F. Sutter, M. Kreuzer, and W. Langhans. 1999. Effect of a prolonged lowdose lipopolysaccharide infusion on feed intake and metabolism in heifers. J. Anim. Sci. 77:2523-2532.

Strang, B. D., S. J. Bertics, R. R. Grummer, and L. E. Armentano. 1998a. Effect of long-chain fatty acids on triglyceride accumulation, gluconeogenesis, and ureagenesis in bovine hepatocytes. J. Dairy Sci. 81:728-739.

Strang, B. D., S. J. Bertics, R. R. Grummer, and L. E. Armentano. 1998b. Relationship of triglyceride accumulation to insulin clearance and hormonal responsiveness in bovine hepatocytes. J. Dairy Sci. 81:740-747.

Subiyatno, A., D. N. Mowat, and W. Z. Yang. 1996. Metabolite and hormonal responses to glucose or propionate infusions in periparturient dairy cows supplemented with chromium. J. Dairy Sci. 79:1436-1445.

Trevisi, E., and G. Bertoni. 2008. Aspirin and health research progress. Nova Science, Hauppauge, NY.

Vazquez-Añon, M., S. Bertics, M. Luck, R. R. Grummer, and J. Pinheiro. 1994. Peripartum liver triglyceride and plasma metabolites in dairy cows. J. Dairy Sci. 77:1521-1528.

Vizcarra, J. A., R. P. Wettemann, J. C. Spitzer, and D. G. Morrison. 1998. Body condition at parturition and postpartum weight gain influence luteal activity and concentrations of glucose, insulin, and nonesterified fatty acids in plasma of primiparous beef cows. J. Anim. Sci. 76:927-936.

Waggoner, J. W., C. A. Löest, J. L. Turner, C. P. Mathis, and D. M. Hallford. 2009. Effects of dietary protein and bacterial lipopolysaccharide infusion on nitrogen metabolism and hormonal responses of growing beef steers. J. Anim. Sci. 87:3656-3668.

Waldron, M. R., T. Nishida, B. J. Nonnecke, and T. R. Overton. 2003. Effect of lipopolysaccharide on indices of peripheral and hepatic metabolism in lactating cows. J. Dairy Sci. 86:3447-3459.

Wildman, E. E., G. M. Jones, P. E. Wagner, R. L. Boman, H. F. Troutt, and T. N. Lesch. 1982. A dairy cow body condition scoring system and its relationship to selected production characteristics. J. Dairy Sci. 65:495-501.

Williams, R., B. E. Speyer, and B. H. Billing. 1961. Serum haptoglobin in liver disease. Gut 2:297-303.

Yao, Z. M., and D. E. Vance. 1988. The active synthesis of phosphatidylcholine is required for very low density lipoprotein secretion from rat hepatocytes. J. Biol. Chem. 263:2998-3004.

Zahra, L. C., T. F. Duffield, K. E. Leslie, T. R. Overton, D. Putnam, and S. J. LeBlanc. 2006. Effects of rumen-protected choline and monensin on milk production and metabolism of periparturient dairy cows. J. Dairy Sci. 89:4808-4818.

Zom, R. L. G., J. van Baal, R. M. A. Goselink, J. A. Bakker, M. J. de Veth, and A. M. van Vuuren. 2011. Effect of rumen-protected choline on performance, blood metabolites, and hepatic triacylglycerols of periparturient dairy cattle. J. Dairy Sci. 94:4016-4027. 